\title{
THE THEME OF POWER IN SCENOGRAPHY BY M. KYPRIIAN (BASED ON L. UKRAINKA'S AND W. SHAKESPEARE'S PLAYS)
}

For sixty years, Myron Kypriian has consistently shaped the attitude of the Ukrainian scene to national and world classics, but still remains an unrecognized master of the original avant-garde scenography of Ukraine of the XX-XXI centuries. Studying the creative work of the artist, we have the opportunity to analyze changes in contemporary art, borrow and improve Ukrainian stage design. The article considers the specifics of the creative approach of the artist M. Kypriian to the creation of productions on the "eternal theme" of power, namely the scenography to the works of L. Ukrainka "The Stone Host" (1971) and W. Shakespeare "Richard III" (1974). The performances are combined by common issues, time interval, production team, which explains the appropriateness of their comparison. The tandem of the artist with the director is investigated. M. Kypriian worked on the performances together with the director S. Danchenko; both artists were at the peak of their youth and creative path. The influence of dramatic material on the work of a theatrical artist is substantiated. Methods of art analysis are used: iconographic, iconological. The presentation of the main material consistently reveals how the artist works on various literary materials (national and world classics) that have common themes. It is noted that M. Kypriian performed a stage design for another play by $W$. Shakespeare, which in some way touched on the theme of power "King Lear" (1969, directed by M. Gilyarovsky). Parallels are drawn between the stage design of M. Kyprian to the performances "The Stone Host", "Richard III" and his other performances, as well as modern productions that are not related to M. Kypriian. The connection between M. Kypriian's stage design and Slavic mythology, geometric architectural forms and rough natural materials has been found. The conclusions identify the specifics of the artist's artistic language; the joint decision of sketch works to two specified performances is named; the principle according to which the motive of power common to the plays of L. Ukrainka and W. Shakespeare is manifested in the visual decision of performances is revealed.

Key words: Ukrainian art, fine art, scenography, works by L. Ukrainka, works by W. Shakespeare.

Сорія ЯНКЕВИЧ, orcid.org/0000-0002-4460-5103 аспірантка кафедри теорії та історії мистецтва Харківської державної академї дизайну і мистеитвв (Харків, Україна) sayankevich@gmail.com

\section{ТЕМА ВЛАДИ У СЦЕНОГРАФІЇ М. КИПРІЯНА (ЗА П'ЄСАМИ В. ШЕКСПІРА ТА Л. УКРАЇНКИ)}

\footnotetext{
Мирон Кипріян протягом шістдесяти років послідовно формував відношення української сцени до національної та світової класики, проте досі залишається невизнаним майстром оригінальної авангардної сиенографії України XX - XXI століття. Вивчаючи творчий доробок мития, маємо можливість аналізувати зміни у сучасному мистецтві, запозичувати та вдосконалювати украйнський сиенічний дизайн. У статті розглянута специфіка творчого підходу художника М. Кипріяна до створення постановок на «вічну тему» влади, а саме сценографія до творів Л. Українки «Камінний господар» 1971 р. та В. Шекспіра «Річард III» 1974 р. Вистави об'єднані спільною проблематикою, часовим проміжком, постановочною командою, щзо пояснює доречність їх порівняння. Досліджено тандем художника з режисером-постановником. Над виставами М. Кипріян працював спільно із режисером С. Данченком; обидва митці знаходилися на піку молодості та творчого шляху. Обгрунтовано вплив драматичного матеріалу на роботу театрального художника. Використано методи мистецтвознавчого аналізу: іконографічний, іконологічний. У викладі основного матеріалу послідовно розкрито як художник праџює над різним літературним матеріалом (національна та світова класика), шчо мають спільну тематику. Зазначено, що М. Кипріян виконував сиенічне оформлення до іншої вистави за В. Шекспіром, яка певним чином торкалися теми влади «Король Лір» (1969, режисер М. Гіляровський). Проведено паралелі між сиенічним дизайном М. Кипріяна до вистав "Камінний господар”, “Річард ІІІ” та інших його вистав, а також сучасних постановок, щзо непов'язані з М. Кипріяном. Знайдено зв'язок сиенічного оформлення М. Кипріяна із слов'янською міфологією, геометричними архітектурними формами та грубими природними матеріалами. У висновках визначено специфіку художньої мови мития; названо спільне
} 
рішення ескізних робіт до двох означених вистав; виявлено принции, за яким проявляється загальний для п'єс Л. Украӥнки і В. Шекспіра мотив влади у образотворчому рішенні вистав.

Ключові слова: українське мистецтвво, образотворче мистеитво, сценографія, твори В. Шекспіра, твори Л. Українки.

Formulation of the problem. After the death of M. Kypriian in the repertoire of the Lviv Theater named after M. Zankovetska has a few performances left with the participation of the artist (where he worked since 1957), but the probability of their writing off increases every day. The theater needs new productions that are in tune with the present of Ukraine, and "yesterday's" performances, no matter how original, are a thing of the past. Carrying out an art study of M. Kypriian's work has scientific potential. Critical analysis has the opportunity to inspire contemporary scenographic art of Ukraine to move towards effective visual design of the stage with adaptation to the needs of the modern theatrical process. First of all, thanks to the individual approach of the artist to the creation of scenography, cooperation with progressive directors (B. Tyahno, S. Danchenko, F. Stryhun), actors (B. Kozak, B. Stupka, O. Hrynko, L. Kadyrova), playwrights (O. Korniychuk, M. Kulish, O. Ogorodnik) past and present. We have the task to establish the name of M. Kypriian as the scenographer who can be inherited, and connect his name with the well-known names of the Ukrainian poetess L. Ukrainka and the English playwright W. Shakespeare. The comparison of the visual solution of M. Kypriian in the performances of L. Ukrainka "The Stone Host" in 1971 and W. Shakespeare "Richard III" in 1974 in the study is due to the common chronology, socio-cultural context, outstanding drama, the theme of power, directing and acting activities within one theater.

Research analysis. In some interviews and articles, the work of M. Kypriian is considered through the prism of the significance of performances for the Ukrainian theater, mainly due to the famous name of the director or actor. In theatrical reviews, the artistic design of the production usually pays indirect attention. In the 21 st century, while studying theater criticism, students focus their critical attention on the analysis of the play, based on the work of actors and directors and the general atmosphere of the stage space. The young researcher lacks knowledge to adequately analyze the musical score and the visual component. We emphasize the importance of art history, specifically art approach, in the study of a particular production, using attributive, iconographic, iconological research methods. In the field of art history today only O. Shpakovych (Shpakovych, 2020: 233-244; Shpakovych, 2018: 208-225) researches the topic.
Also, information about the art of M. Kypriian can be found in his own publications (Kypriian, 2015; Kypriian, 2011; Kypriian, 2007), publications on theater (Dobrovolska, 2016: 127-139; Harbuziuk, 1994: 28-32; Mykhalyuk, Svetlana. 1975) and fine arts (Sidorenko, 2006), briefly in dissertations (Klimko, 2014: 189-201).

The purpose of the article - consider and compare the artistic solution of the artist M. Kypriian for two productions united by the theme of power: "The Stone Host" in 1971 and "Richard III" in 1974.

Presenting main material. Some topics cannot be exhausted, completed and forgotten. They appeal to the human essence. They are called "eternal". The plays by L. Ukrainka "The Stone Host" and W. Shakespeare's "Richard III" are written on the same theme, although their authors are divided by ages. M. Kypriian's understanding of the theme of power, human thirst for supremacy, recognition, domination originated during the war, even in childhood. So for the artist, the question: what can be common between Ukrainian modern literature and English classics - did not create a problem. When a person from the present turns to the past, he is looking for something clear and close to himself, to his time. Eventually, she realizes that the world around her is changeable, but nothing, not even time, can change the essence of man.

Shakespeare's art is passionate. In the plays of the playwright there are always raging passions that revolve around man and his instincts. One of the central themes of the Englishman's work, along with the romance of love (plays "Romeo and Juliet", "Othello"), should be considered the theme of power. She is imbued with the plays "King Lear", "Macbeth", historical chronicles, which includes "Richard III". It is the play "Richard III" (circa 1591) that is most attractive to the theater because of the vivid image of the protagonist, which is interesting to interpret. Shakespeare's play is historical, but in many ways subjective and achronical. First, the exaggerated negativity of Richard Gloucester's personality is probably borrowed from the works of Richard III's adversary, John Morton, Thomas More's The Story of Richard III, and Raphael Hollished's Chronicles. The plot of the play revolves around the insidious activities of a terrible hunchback, deprived of beauty, but endowed with reason. W. Shakespeare describes situations in which the truth is clearly stated that the mind is not always associated with morality, that the head 
is the primary weapon from which the destruction of humanity is created. Thus, in order to gain power, Richard destroys the heirs of King Edward IV, flatters the nobility in order to be sympathetic to his candidacy, eliminates dissenters, marries for complacency, "appropriates" the widow of the deceased king. In critical literature, the play is called a monodrama, distinguishing Richard as an aggressive individual who feels like a "little man" with great ambitions, and who, for the sake of general anxiety, will resort to any tricks.

The dramatic poem "The Stone Host" by L. Ukrainka (1912) was also loved in the theater. The writer has always felt fascinated by the past, so the heroes of her works lived in ancient times. However, they have always felt what anyone can feel at all times. L. Ukrainka's play is inspired by medieval legends and their adaptation by O. Pushkin's "The Stone Host" of the "Boldin Autumn" period (1830). Researchers of the Ukrainian writer's work note that the author "feels free within the world plot" (Nenadkevych, 2002: 30-31). The poetess approached the interpretation of the Spanish legend in a subtle and romantic way in a feminine way. First, she introduced the image of Don Juan, the man-seducer, into Ukrainian literature. Secondly, it endowed a woman with masculine traits: rigidity of character, authority and selfishness. Third, she introduced additional characters to the play, bringing the Commander to the forefront of the ideological beginning of the drama. "Her idea is the victory of the stone, conservative principle embodied in the Commander, over the forked soul of the proud, selfish woman Donna Anna, and through her over Don Juan, "the knight of freedom"" (Ukrainka, 1979: 395-397), as the writer herself noted. Her drama became an expression of Ukrainian feminism and a woman's self-affirmation in Ukrainian art: "One way or another, but even in our literature there is" Don Juan "own, not translated, original because it was written by a woman" (Ukrainka, 1979: 395-397.).

The performances "The Stone Host" (L. Ukrainka, 1971) and "Richard III" (W. Shakespeare, 1974), created by S. Danchenko and M. Kypriian, are considered significant for the development of Ukrainian art (Dobrovolska, 2016: 127-139). When today's wellknown theater director Serhiy Danchenko began his original path in art on the stages of Lviv theaters, the artist M. Kypriian did the same. The creative tandem of artists began on the stage of the theater. M. Zankovetskaya in collaboration with the plays "The Widower" by O. Stein (1965), "The Man Overboard" by A. Shkolnik (1966), "McLean Grass" by M. Kulish (1967). But the artists reached their true creative apogee when S. Danchenko became the main director of the theater (period between 1970 and 1978): "... Already the first steps on the way of joint solution of the stage action by the director and the scenographer allowed to organically combine a high level of artistic generalizations with effective lines of development of images of heroes" (Sidorenko, 2006: 625).

$\mathrm{S}$. Danchenko is the heir of the theatrical profession. In his veins flowed the hot blood of stage fortune, which was genetically transmitted from parents, actors of the theater after M. Zankovetska Volodymyr Danchenko and Vira Polinska; as well as from a distant relative, director Vladimir NemirovichDanchenko. S. Danchenko sought to create a highquality psychological theater, and the Lviv period of creativity became the beginning of the fulfillment of his dreams. Chronologically, the first was the work of artists on the play "The Stone Host" (premiere 19 February, 1971). The production reflected the dialogue between L. Ukrainka's text and his stage vision of the people of theater. The director brought to the fore the actions of the three main characters of the play (Commander -O. Hrynko, Don Juan - F. Stryhun, Donna Anna - L. Kadyrova). With the help of the original visual solution, the play had a clear metaphor for power - the driving force that guided the thoughts and actions of the characters. Man's desire for power is a movement upwards. The set designer expressed this process in the form of a "pyramid", where there is room only for someone alone. The play has a pronounced constructivist solution, which shows the quintessence of the basic visual techniques of the artist. The metal structure is inscribed by M. Kypriian in the shape of a triangle. The composition on the scenographer's sketch for the play "Loyalty" (M. Zarudny), performed a year before "The Stone Host", had a similar form, but it was a more simplified geometric decoration that did not have such a functional load. The design for S. Danchenko's production had two axes - vertical and horizontal, which formed a looped spiral. Researchers note that "the spiral is one of the constant, though not often repeated, constructive motives of M. Kypriian" (Mykhalyuk, 1975: 24.). Suffice it to mention the performances "Faust and Death" (1960), "Talentless" (1987), "Hutsulka Xenia" (1997), designed by the artist.

The sketch of M. Kypriian's scenery for "The Stone Host" fits into a style acceptable to the artist: a dark background, a drawing with water-based paints. On a black background, the scenographer used a prism to mark the plane of the stage, and above it he drew a pointed structure that hung in the air like a flying island. An analogy is formed with the historical fate of the legend of Don Juan, which also froze over the 
centuries, and still attracts the attention of contemporary artists. M. Kypriian together with the director S. Danchenko tried to find her a place in the Ukrainian art of the stage. Despite the predominant black color, the artist created a warm sketch. On it imitation of gloss of metal is combined with warm yellow color of horizontal lines of a geometrized design. M. Kyprian's "Flying Island" remotely resembles the hut of Baba Yaga. The visual relationship is mainly possible due to the presence in the artist's design of substrates that resemble "legs". Thus, the stage scenery acquires spirituality, becomes an equal part of the dramatic action, along with the actors (just as the house of Baba Yaga in Slavic mythology had the characteristics of a living being).

The specific architectural scenery for the "The Stone Host" became the center of stage action: "With the development of stage action, the monolithic structure gradually opened its internal structure, thus creating a multi-storey architectural structure" (Sidorenko, 2006: 624). The visual design of M. Kypriian led to a mise-en-scène solution of the production as a whole, where the lyrical heroes in their quest for power moved forward to the top materially defined by the artist: "Thus, the boundary was visually determined, beyond which the human ceased to exist and turned into a stone, dead" (Harbuziuk and Borovska, 1994: 30). The semantic load of the stage construction was noted by researchers and eyewitnesses of the play: "Gradually in our imagination the conditional structure turned into a monolith of force and power, which is aimed at all the thoughts of the characters" (Harbuziuk and Borovska, 1994: 30). The only decorative installation became an expressive tool of ideas of both the director and the playwright. The artist created the costumes of the characters, based on the principle of contrast, which comes from the conflict laid down by the playwright between life and death. The dual nature of human existence was picked up by the director: "The whole play is a duel of ideas, a dispute of worldviews - a constant struggle between the living and the dead" (Harbuziuk and Borovska, 1994: 31) In addition, M. Kypriian understood the general principle of theatrical action, which is based on conflict. The contrasting color palette of the costumes was not the original discovery of the set designer, but was a manifestation of the experience and analytical thinking of the theatrical figure. The director and artist of the play used an old stage attribute - a mask, which added semantic layering to the acting. Masks emphasized the unnaturalness of actions and hypocrisy of characters, figuratively "depriving people of individual traits" (Harbuziuk and Borovska, 1994: 31).
The play of 1971 is based on the national literature of the early twentieth century, but its visual design (as well as directing), today causes more emotion and interest, compared to many of today's theatrical experiments. M. Kypriian's avant-garde stage construction, which is compared to the "medieval castle tower" and "impregnable mountain" (Sidorenko, 2006: 625) is available to a wide range of Ukrainians in sketch format through museum exhibitions in Lviv and Kyiv. The conciseness and capacity of the stage designer's artistic language became the determining factors of the performance's success and determined its visibility in art.

The next joint project of director S. Danchenko and artist M. Kypriian, where the artists pondered together on the theme of power, was the play "Richard III" (premiere 11 May, 1974). Researchers note that the theater after M. Zankovetska is characterized by chronic "faith in world justice" and "historical optimism" (Dobrovolska, 2016: 134). For many years there has been a process of attraction of theater artists to socially significant topics and the production of active artistic philosophy. Shakespeare's drama became the object of the troupe's theatrical productions both before and after the play "Richard III" (most of which were arranged by M. Kypriian). We focus our research on the chronicles of the life of Richard III, because no work by W. Shakespeare raises the question of power as sharply as this "theater-loved" drama. Until 1974, M. Kypriian became an accomplice in the creation of another Shakespearean play about the desire for a monarchical crown "King Lear" (1969, directed by M. Gilyarovsky). The general spatial solution of the production was a set of tragic meanings embedded in the abstract form: "things on the stage are few: three planes - an oak platform, over which the vertical axis rotates a disk and a chain hanging from the grate to the floor" (Shpakovych, 2020: 242). Because of the symbolism of variable semantics, M. Kypriian appeals to Shakespeare's pervasive theme of power. The artist recalled: "In the play "King Lear" I used the attributes of human misery in the struggle for power, the symbolic machine of a block in infinity: a planet or a ringing coin?" (Kypriian, 2007: 174). M. Kypriian focuses the viewer's attention on the symbols of power and might, generates an associative series by emphasizing one important detail. He was guided by this principle in the design of "King Lear", and continued it in "Richard III". Researchers interpret this feature of the artist as a tendency to create a "theater of maximum associations" (Mykhalyuk, 1975: 24). For S. Danchenko's performance, the artist chose an unambiguous symbol of power - the crown. And 
although the symbol of the monarchy was executed in all the rules of sham pomp and clarity, its place was clearly indicated by M. Kypriian in the sketch of the scenery: the edge of the stage sky. During the stage action, the crown was also "more quickly guessed at in the dim reflections and gloomy contours than in its unambiguous specificity" (Sidorenko, 2006: 731). Thus, the artist "announced" his own position on Shakespeare's drama. It would seem that the location is a trifle, but this creates controversy. "Is power the limit of all dreams? Perhaps the power lies in something else, more noble: honor, justice, truth". M. Kypriian created a simple but effective artistic language. And, as they say in the people, everything ingenious is very simple.

For the play "Richard III", the artist also chose the constructivist direction of the visual solution. In a sketch recognizable by its style, M. Kypriian outlined the geometry of space: a system of lifting mechanisms drives wooden platforms located around the perimeter of the stage. The simple principle of the stage design is vividly depicted by the set designer: a traditional black background on which rectangular prisms are depicted with a color stretch - from white to orange (to indicate the wooden material of the scenery). The artist creates the effect of a lighted scene on a sketch. The composition of the figure forms a geometric circle, where the prisms look like orange sunlight.

The set designer developed the theme with one wooden platform from the play "King Lear". In this way, he not only expanded the boundaries of the stage, but also created a multi-level model of mise-enscène drawing. With the help of moving mechanisms in front of the audience there was a transformation of the decorative installation, and actors (F. Strygun, B. Stupka - Richard; L. Kadyrova, A. Kornienko Lady Anna; B. Kozak - Clarence) were able to play on two tiers around perimeter of the scene. Constructivist scenography embodied a medieval castle, with its power and insidiousness. In the artistic world created by M. Kypriian, power and power belonged to the ancient castle rather than to any of its inhabitants. The set designer felt that the castle was alive: "The space of the tragedy was delineated by a system of interconnected platforms on chains that opened with a roar to release someone into the battle arena and closed to bury another victim of Richard's aggression" (Sidorenko, 2006: 731). M. Kypriian deliberately used the sound effects generated by the chosen stage construction: the creaking of a tree, the rumble of a lowered platform, the rattle of a metal chain. There was an imitation of the real atmosphere of a medieval castle, its aggression and danger. The stage space of the play was spiritual. He had a historical memory, "whispering" his stories to the audience. The castle represented a constancy that no ruler had.

At the heart of M. Kypriian's artistic solution is a rigid wooden decoration with metal lifting elements: "Texture of untreated wood, rusty metal, weaving of tarred ship ropes, barrels, leather thrown on the platform" (Sidorenko, 2006: 732). Unlike "The Stone Host", the play "Richard III" cuts off the sophistication of form and appeals to rough materials.

The constructivist scenery in the play is combined with the cubofuturism of the costumes, which is expressed in the difference in the ways of geometrization of the depicted objects. M. Kypriian's costumes (for all Shakespeare's plays) are presented succinctly and expressively, reminiscent of the works of O. Exter of the period of fascination with cubism (the composition in M. Kypriian's sketches is more laconic). Researcher O. Shpakovych explored the peculiarities of M. Kypriian's costume design, emphasizing Shakespeare's dramas: "All sketches of costumes for these performances, created with a difference of ten years, are a kind of harmonious series of works created in an applicative way using colored and tonal pastel stretch marks" (Shpakovych, 2018: 217-218). The artist's costumes have a graphic imprint of the avant-garde. Unfortunately, after sewing clothes, the artist's artistic decision was partially lost, and the artist's propensity for avant-garde thinking was fully understood only through his sketches.

The geometrized silhouette of Richard in the center of the artist's sketch work for the performance saturates the decorative scheme with figurative meaning. The presence of characters in the sketches is not decisive. The artist depicts them schematically, conditionally, without detailing the image or accumulating an empty space of scenery, as a painter could do. The very fact of the artist's formation of a mise-en-scène drawing is important, which is a prerequisite for a theatrical production. It testifies in favor of threedimensional thinking of M. Kypriian, his understanding of the laws of theater.

M. Kypriian's artistic language is rich. On the example of the play "Richard III" we see the range of artistic tools of the stage designer: “... tendency to various scenographic experiments with light, color, texture of the material. When exactly the halftones, shades, illumination of the planes, scenographic installation, costumes became artistic and visual means" (Klimko, 2014: 193). The performances "The Stone Host" (1971) and "Richard III" (1974) proved the uniqueness and power of M. Kypriian's scenography. Judgments of researchers in the field of art confirm the universality of the artist's language: 
"The desire to penetrate equally from national problems to universal and vice versa, to find consonance of national ideas with universal allows Kypriian to create interesting meaningful, associative images of performances" (Harbuziuk, Borovska, 1994: 32).

Plays by W. Shakespeare and L. Ukrainka are still of interest to the theatrical community ("The Stone Host": L. Ukrainka National Academic Russian Drama Theater, 2002, directed by M. Reznikovych; Lesya Kurbas Lviv Academic Theater, 2002, directed by V. Kuczynski, Theater on the Hem, 2020, directed by I. Urivsky, Richard III: Theater in a Basket, 2007, directed by I. Volytska, Ivan Franko National Academic Drama Theater, 2016, A. Varsimashvili; Golden Gate ", 2018, directed by K. Crombholtz). Through world-class plots, artists convey their pain and the pain of past generations. After all, returning to the eternal theme, the artist himself adheres to eternity, becomes part of it.

Conclusions. The scenographic activity of M. Kypriian to two stage productions "The Stone Host" (1971) and "Richard III" (1974), united by the theme of power, was considered at the article. It is proved that the artistic techniques used by the artist in the design of the performance after national literature do not differ in the strength of visual and psychological influence from the world classics designed by M. Kypriian. The moral, philosophical and social issues raised in L. Ukrainka's dramatic poem and W. Shakespeare's play are at a high dramatic level, and have found their place in the theatrical interpretation of director S. Danchenko and artist M. Kypriian. Both authors were inspired by the chosen literary basis and went from the command of the text to their own reflections.

It was found that the performances "The Stone Host" and "Richard III" were based on the principle of conditional avant-garde constructivist scenography. The basis of M. Kypriian's visual solution to both productions is geometrization and monumental- ity, generated by the influence of ideas of such artistic directions as constructivism, cubism (avant-garde in general). The set designer used combinations in which different directions are combined into a single artistic solution, enriched by the artist's painting experience. The general solution of sketch works is a combination of constructivist scenery and colorfully capacious costumes in the style of cubofuturism. In the play "Richard III", the artist experiments with the plastic possibilities of light. M. Kypriian builds a visual image of performances on the principle of a combination of colored geometric planes on a black background. It is also typical for an artist to incorporate a mise-en-scène drawing into a sketch of scenery. Without leaving the two-dimensional plane of the sketch, the artist created movement, dynamics and perspective with minimal visual means. It is the movement and the contrasting color combination that form the tragic artistic language of M. Kypriian, which is important in the artistic reading of both plays by W. Shakespeare and dramatic poems by L. Ukrainka.

A way of visually realize the common motive of power for the plays of L. Ukrainka and W. Shakespeare has been found. M. Kypriian used an artistic metaphor through specific images-symbols (royal crown), a decorative construction (a monolithic metal tower with a spiral principle of mise-en-scène, the internal structure-transformer of a medieval castle). To implement the ideas of the scenographer, the principle of using rigid scenery (metal in "The Stone Host" and wood in "Richard III") became decisive. The material of the constructions became the conductor of the power and authority of the architectural decorations, to which M. Kypriian gave the functions of the masters of the stage. In his work, the set designer, through the prism of world-renowned plots, saw the harsh reality, which he modeled into a new, his own artistic construction with a coded generaltragic meaning.

\section{BIBLIOGRAPHY}

1. Гарбузюк М., Боровська Л. Мирон Кипріян. Украӥнський театр. 1994. № 2. С. 28-32.

2. Добровольська Т. Розвиток Львівського національного театру імені Марії Заньковецької у 50 - 70-х роках ХХ ст.: художні процеси та історичний контекст, Українське мистецтвознавство: матеріали, дослідження, рецензї., № 16, 2016: 127-139.

3. Кипріян М. В. Все в минулому. Львів : Панорама, 2007. 300 с.

4. Кипріян М. В. Спогади. Живопис. Сценографія. Л.: ЗУКЦ, 2011. 328 с.

5. Кипріян М. В. Костюм до театральних вистав. Львів : ВД Панорама, 2015. 148 с.

6. Климко 3. В. Виявлення тенденцій і особливих відмінностей в творчій біографії Є. М. Лисика в порівнянні із досягненнями інших майстрів сценографії. Вісник Національного університету "Львівська політехніка". Архітектура. 2014. № 793. С. 189-201.

7. Леся Українка. Зібрання творів у 12 тт. К.: Наукова думка, 1979 р., т. 12, с. 395-397.

8. Михалюк С. Золотий переріз. Український театр. 1975, № 1.

9. Нариси з історії театрального мистецтва України XX століття. В. Сидоренко (голова) та ін.; Акад. мистецтв України, Ін-т пробл. сучас. мистецтва. Київ : Інтертехнологія, 2006. 1064 с. 
10. Ненадкевич Є. Українська версія світової теми про Дон Жуана в історичнолітературній перспективі. Дон Жуан у світовому контексті. Упор. В. Агєєва. Київ: Факт, 2002. С. 30-31.

11. Шпакович О. О. Сценографічна діяльність М. Кипріяна в 60-х роках XX ст., Народознавчі зошити, № 1 (151), 2020. 233-244.

12. Шпакович О. Театральний костюм у творчості Мирона Кипріяна. Вісник Львівської національної академії мистеитвв. 2018. № 38. С. 208-225.

\section{REFERENCES}

1. Harbuziuk M., Borovska L. Myron Kypriian [Myron Kypriian]. Ukrainskyi teatr. 1994. № 2. S. 28-32 [in Ukrainian].

2. Dobrovolska T. Rozvytok Lvivskoho natsionalnoho teatru imeni Marii Zankovetskoi u 50-70-x rokakh KhKh st.: khudozhni protsesy ta istorychnyi kontekst [Development of the Lviv National Theater named after Maria Zankovetska in the $50 \mathrm{~s}-70 \mathrm{~s}$ of the twentieth century: artistic processes and historical context], Ukrainske mystetstvoznavstvo: materialy, doslidzhennia, retsenzii., № 16, 2016: 127-139. [in Ukrainian].

3. Kypriian M. V. Vse v mynulomu [All in the Past]. Lviv : Panorama, 2007. 300 s. [in Ukrainian].

4. Kypriian M. V. Spohady. Zhyvopys. Stsenohrafiia [Memories. Painting. Scenography]. L.: ZUKTs, 2011. 328 s. [in Ukrainian].

5. Kypriian M. V.Kostium do teatralnykh vystav [Costume for Theatrical Performances]. Lviv : VD Panorama, 2015. 148 s. [in Ukrainian].

6. Klymko Z. V. Vyiavlennia tendentsii i osoblyvykh vidminnostei v tvorchii biohrafii Ye. M. Lysyka v porivnianni iz dosiahnenniamy inshykh maistriv stsenohrafii [Identification of tendencies and special differences in the creative biography of EM Lysyk in comparison with the achievements of other masters of scenography]. Visnyk Natsionalnoho universytetu "Lvivska politekhnika". Arkhitektura. 2014. № 793. S. 189-201. [in Ukrainian].

7. Lesia Ukrainka. Zibrannia tvoriv u 12 tt [Collected works in 12 vols]. K.: Naukova dumka, 1979 r., t. 12, s. 395-397. [in Ukrainian].

8. Mykhaliuk S. Zolotyi pereriz [Golden Section]. Ukrainskyi teatr. 1975, № 1. [in Ukrainian].

9. Narysy $\mathrm{z}$ istorii teatralnoho mystetstva Ukrainy XX stolittia [Essays on the history of theatrical art of Ukraine of the twentieth century]. V. Sydorenko (holova) ta in.; Akad. mystetstv Ukrainy, In-t probl. suchas. mystetstva. Kyiv : Intertekhnolohiia, 2006. $1064 \mathrm{~s}$. [in Ukrainian].

10. Nenadkevych Ye. Ukrainska versiia svitovoi temy pro Don Zhuana v istorychnoliteraturnii perspektyvi. Don Zhuan u svitovomu konteksti [Ukrainian version of the world theme about Don Juan in the historical-literary perspective]. Upor. V. Ahieieva. Kyiv: Fakt, 2002. C. 30-31. [in Ukrainian].

11. Shpakovych O. O. Stsenohrafichna diialnist M. Kypriiana v 60-kh rokakh KhKh st. [The stage design by Myron Kypriian in 60s of the 20th century], Narodoznavchi zoshyty, №1 (151), 2020. 233-244. [in Ukrainian].

12. Shpakovych O. Teatralnyi kostium u tvorchosti Myrona Kypriiana [Theatrical costume by Myron Kypriian]. Visnyk Lvivskoi natsionalnoi akademii mystetstv. 2018. № 38. S. 208-225 [in Ukrainian]. 